\title{
Evaluation of N/LP Ratio as a Predictor of Disease Progression and Mortality in COVID-19 Patients Admitted to the Intensive Care Unit
}

\author{
Yoğun Bakım Ünitesine Kabul Edilen KOVID-19 Hastalarında N/LPOranının \\ Hastalık Illerlemesi ve Mortalitenin Öngörüsü Olarak Değerlendirilmesi
}

\author{
Basak CAKIR GUNEY $\odot$, Mert HAYIROGLU $\odot$, Didar SENOCAK $\odot$, Vedat CiCEK $\odot$, Tufan $\operatorname{CINAR} \odot$, \\ Mustafa KAPLAN $\odot$
}

\begin{abstract}
Ethics Committee Approval: This study was approved by University of Health Sciences Hamidiye Clinical Research Ethics Committee, 7 July 2021, 2020.07.10- 52

Conflict of interest: No author involved in this investigation has any conflicts of interest to be disclosed.

Funding: None.

Informed Consent: Not applicable.

ABSTRACT

Objective: This research aimed to evaluate whether the neutrophil to lymphocyte and platelet $(N / L P)$ ratio may be used to predict the risk of admission to the intensive care unit (ICU), the need for mechanical ventilation and in-hospital mortality in Coronavirus disease 2019 (COVID19) cases.

Methods: The study was conducted retrospectively on the data of 134 COVID-19 patients who were admitted to the ICU. The N/LP ratio was calculated as follows: neutrophil count $x 100$ (lymphocyte count $x$ platelet count). Each member of the research cohort was categorised into 1 of 2 groups based on their survival status (survivor and non-survivor groups).

Results: In total, 82 (61\%) patients died during the ICU stay. Patients who required mechanical ventilation and died in the ICU stay had significantly higher N/LP ratio than those who did not require it and survived [10 (IQR=4.94-19.38) vs 2.51 (IQR=1.67-5.49), $p<0.001]$ and [11.27 $(I Q R=4.53-30.02)$ vs 1.65 (IQR=1-3.24), $p<0.001]$, respectively. The $N / L P$ ratio was linked with the requirement of mechanical ventilation and in-hospital death according to multivariable analysis. In receiver operating characteristic curve analysis, we found that N/LP in predicting admission to the ICU was $>4.18$ with $61 \%$ sensitivity and $62 \%$ specificity, it was $>5.07$ with $74 \%$ sensitivity and $73 \%$ specificity for the need for mechanical ventilation, and $>3.69$ with $81 \%$ sensitivity and $81 \%$ specificity to predict in-hospital death.

Conclusion: To our knowledge, this is the first study showing that the N/LP ratio, which is a novel and widely applicable inflammatory index, may be used to predict the risk of ICU admission, mechanical ventilation and in-hospital death in patients with COVID-19 disease .
\end{abstract}

Cite as: Cakir Guney B, Hayiroglu M, Senocak D, Cicek V, Cinar T, Kaplan M. Evaluation of N/LP ratio as a predictor of disease progression and mortality in COVID-19 patients admitted to the intensive care unit. Medeni Med J. 2021;36:241-8.
Keywords: COVID-19, N/LP ratio, in-hospital mortality, predictive value

Öz

Amaç: Bu araştırma, Koronavirüs hastalığı 2019 (KOVID-19) hastalarında nötrofil/lenfosit ve platelet $(N / L P)$ oranının yoğun bakım ünitesine (YBÜ) kabul riskini, mekanik ventilasyon ihtiyacını ve hastane içi mortaliteyi tahmin etmek için kullanılıp kullanılamayacağını değerlendirmeyi amaçlamıştır.

Yöntem: Çalışma, yoğun bakım ünitesine yatırılan 134 KOVID-19 hastasının verileri üzerinden geriye dönük olarak yapıldı. N/LP oranı șu șekilde hesaplandı: nötrofil sayısı x 100/(lenfosit sayısı x platelet sayısı). Araştırma grubunun her bir üyesi, hayatta kalma durumlarına göre (hayatta kalan ve hayatta kalmayan gruplar) 2 gruptan 1 'ine ayrılmıștır.

Bulgular: Toplamda 82 (\%61) hasta yoğun bakımda kalıs sırasında öldü. Yoğun bakım ünitesinde mekanik ventilasyona ihtiyaç duyan ve ölen hastaların N/LP oranı, gerektirmeyen ve hayatta kalanlara göre anlamlı olarak daha yüksekti $[10(I Q R=4,94-19,38)$ vs. 2,51 $(I Q R=1,67-5,49), p<0,001]$ ve sırasıyla [11,27 (IQR=4,53-30.02) vs. $1.65(I Q R=1-3,24), p<0,001]$. N/LP oranı, cok değisskenli analize göre mekanik ventilasyon gereksinimi ve hastane içi ölümle bağlantılıydı. Alıcı işletim karakteristik eğrisi analizinde, yoğun bakım ünitesine kabulü öngörmede N/LP'nin \%61 duyarlılı ve $\% 62$ özgüllük ile $>4,18$, mekanik ventilasyon ihtiyacı icin $\% 74$ duyarlılık ve $\% 73$ özgüllük ile $>5.07$ hastane içi ölümü öngörmede \%81 duyarlılık ve \%81 özgüllük ile >3,69 olduğunu bulduk. Sonuç: Bildiğimiz kadarıyla bu, yeni ve yaygın olarak uygulanabilir bir enflamatuvar indeks olan N/LP oranının KOVID-19 hastalarında yoğun bakıma yatış, mekanik ventilasyon ve hastane içi ölüm riskini tahmin etmek için kullanılabileceğini gösteren ilk çalışmadır.

Anahtar kelimeler: KOVID-19, N/LP oranı, hastane içi ölüm oranı, tahmini değer
Received: 10 May 2021

Accepted: 21 July 2021

Online First: 30 September 2021

Corresponding Author:

T. Cinar

ORCID: 0000-0001-8188-5020

Health Sciences University,

Sultan Abdülhamid Han

Training and Research Hospital, Department of Cardiology, Istanbul, Turkey

drtufancinar@gmail.com

B. Cakir Guney

ORCID: 0000-0003-2389-2833

M. Kaplan

ORCID: 0000-0003-2961-7656

Health Sciences University, Sultan

Abdülhamid Han Training and Research Hospital, Department of Internal Medicine, Istanbul, Turkey

M. Hayiroglu

ORCID: 0000-0001-6515-7349

Health Sciences University, Dr. Siyami Ersek Training and Research Hospital, Department of Cardiology, Istanbul, Turkey

D. Senocak

ORCID: 0000-0001-9840-9004 Health Sciences University, Haydarpasa Numune Training and Research Hospital, Department of Internal Medicine, Istanbul, Turkey

V. Cicek

ORCID: 0000-0002-3763-0570 Health Sciences University, Sultan Abdülhamid Han Training and Research Hospital, Department of Cardiology, Istanbul, Turkey

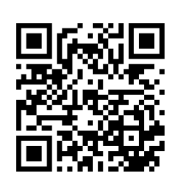




\section{INTRODUCTION}

Coronavirus disease 2019 (COVID-19) caused by severe acute respiratory syndrome coronavirus-2 (SARS-CoV-2) has been a pandemic since December 2019. As reported by the WHO (World Health Organization) in March 2021, over 114 million people in 223 countries were infected with COVID-19 and over 2.5 million people died ${ }^{1}$. The incubation period of the infection varies between two and 14 days, and the contagious period begins within one to two days before the onset of symptoms ${ }^{2}$. In most cases, the infection is mild and does not require hospitalisation ${ }^{3}$. However, moderate or severe cases usually present with typical lung infiltrations. Patients with pulmonary involvement and severe respiratory distress may rapidly develop acute respiratory distress syndrome (ARDS), and most of these patients require mechanical ventilation ${ }^{4}$. The rapid development of an inflammatory response is one of the most significant prognostic factors in COVID19 infection. Elevated C-reactive protein (CRP), CRP/albumin ratio (CAR), ferritin, interleukin-6 (IL-6), white blood cell count (WBC) and reduced lymphocyte, albumin, and platelet levels are the indicators of increased inflammatory response $e^{5,6}$. Therefore, inflammatory parameters can be used to determine the prognosis of COVID-19 cases $^{5,6}$.

Recently, the neutrophil to lymphocyte and platelet (N/LP) ratios were developed based on neutrophil, lymphocyte, and platelet counts to evaluate patients' inflammatory status ${ }^{7}$. A high N/LP ratio was linked to poor outcomes in subjects with sepsis ${ }^{7}$. Moreover, this ratio was demonstrated to have value in predicting the risk of death in subjects following abdominal surgery and cardiovascular surgery ${ }^{8,9}$. However, the predictive value of the N/LP ratio concerning intensive care unit (ICU) admission, the need for mechanical ventilation and in-hospital death in COVID-19 subjects is unknown. Because evaluation of the N/LP ratio is a noninvasive method and N/LP ratio is a widely available and easily obtained parameter as part of a complete blood count $(\mathrm{CBC})$, we examined whether this ratio can be used to predict the risk of admission to the ICU, the need for mechanical ventilation, and in-hospital mortality in COVID-19 cases.

\section{MATERIAL and METHOD}

In this retrospective and observational investigation, the cases of COVID-19 patients who were admitted to the ICU due to COVID19 pneumonia were examined. Our hospital was designated as a pandemic institution by the Ministry of Health in Turkey. In this investigation, only moderate and severe COVID-19 cases requiring an ICU stay were analyzed. Patients under 18 years of age, pregnant patients, patients with a terminal malignancy, and patients who had been diagnosed with one or more hematological diseases were not included. The demographic properties and laboratory data of all patients were accessed through the hospital's electronic database. In addition to specific computed thoracic tomography findings, RT-PCR was used to confirm the diagnosis COVID-19 disease in all cases. The study was conducted in accordance with the Good Clinical Practice guidelines of the Declaration of Helsinki and approved by both the Scientific Research Committee of the Ministry of Health of Turkey and the Local Ethics Committee (approval number: 52-10/07/2020). Informed consent was not required because the research protocol was retrospective.

\section{Laboratory analysis}

Biochemical and hematological parameters were determined using blood samples taken from the patients during routine ICU follow-up. In all cases, CRP, D-dimer, procalcitonin, ferritin and troponin levels, which are frequently examined in the ICU, were also evaluated. The N/LP ratio was calculated from the CBC as follows: Neutrophil count x 100 / (lymphocyte count $x$ platelet count). 
B. Cakir Guney et al. Evaluation of N/LP Ratio as a Predictor of Disease Progression and Mortality in COVID-19 Patients Admitted to the Intensive Care Unit

\section{Statistical analysis}

Statistical analyses were performed with Statistical Package for the Social Sciences 20.0 software (SPSS Inc., IL, USA). A Kolmogorov-Smirnov test was conducted to assess whether the continuous variables had a normal distribution. Levene's test was also conducted to determine the variance equality. The median (interquartile range [IQR]) was used to display continuous variables. The categorical variables were displayed as numbers and percentages (\%). Student's t-test and the Mann-Whitney $U$ test were used to assess variables with and without normal distribution, respectively. Multivariate logistic regression analysis was conducted to identify the association between various parameters and ICU admission, ventilation and in-hospital mortality. Parameters that yielded a p-value $<0.05$ in the univariable logistic regression analysis were entered into a multivariable logistic regression analysis using the Backward LR method. All variables were tested regarding the day they were obtained from the patients. To determine the sensitivity and specificity of the N/LP ratios and cut-off values for predicting admission to the ICU, the need for ventilation and in-hospital death, receiver operating characteristics (ROC) curves were used. A p-value $<0.05$ was considered statistically significant.

\section{RESULTS}

A total of 134 patients with COVID-19 disease

Table 1. Comparison of demographic, and clinical characteristics of all cases included in the study.

\begin{tabular}{|c|c|c|c|}
\hline & $\begin{array}{l}\text { Survivors } \\
(\mathrm{n}=52)\end{array}$ & $\begin{array}{l}\text { Non-survivors } \\
(\mathrm{n}=\mathbf{8 2})\end{array}$ & $\begin{array}{l}\mathbf{p} \\
\text { value }\end{array}$ \\
\hline Age, years & $65(52-75)$ & $72(63-81)$ & $0.016^{*}$ \\
\hline Male gender, n (\%) & $29(55.8)$ & $52(63.4)$ & 0.379 \\
\hline Hypertension, n (\%) & $29(55.8)$ & $46(56.1)$ & 0.970 \\
\hline Diabetes mellitus, n (\%) & $19(36.5)$ & $26(31.7)$ & 0.565 \\
\hline $\begin{array}{l}\text { Chronic obstructive lung } \\
\text { disease, } \mathrm{n}(\%)\end{array}$ & $4(7.7)$ & $13(15.9)$ & 0.154 \\
\hline Asthma, n (\%) & $2(3.8)$ & $2(2.4)$ & 0.641 \\
\hline $\begin{array}{l}\text { Chronic renal failure, } \\
\mathrm{n}(\%)\end{array}$ & $9(17.3)$ & $22(26.8)$ & 0.196 \\
\hline $\begin{array}{l}\text { Cerebrovascular } \\
\text { accident, n (\%) }\end{array}$ & $3(5.8)$ & $7(8.5)$ & 0.740 \\
\hline $\begin{array}{l}\text { Congestive heart failure, } \\
\mathrm{n}(\%)\end{array}$ & $17(32.7)$ & $34(41.5)$ & 0.306 \\
\hline
\end{tabular}

Continuous variables are presented as median values and interquartile ranges (IQR), and nominal variables as frequencies.

${ }^{*} \mathrm{p}<0.05$

Table 2. Laboratory results of all cases upon admissiom to the intensive care unit.

\begin{tabular}{|c|c|c|c|}
\hline & $\begin{array}{l}\text { Survivors } \\
(\mathbf{n}=52)\end{array}$ & $\begin{array}{l}\text { Non-survivors } \\
(\mathbf{n}=\mathbf{8 2})\end{array}$ & p value \\
\hline Hemoglobin, g/dL & $11.6(10.1-13.7)$ & $10.9(9.6-13.0)$ & 0.274 \\
\hline White blood cell count, cells $/ \mu \mathrm{L}$ & $9.9(7.2-12.5)$ & $8.2(5.9-12.5)$ & 0.278 \\
\hline Platelet count, cells $/ \mu \mathrm{L}$ & $254(200-325)$ & $206(152-271)$ & $0.004^{*}$ \\
\hline Neutrophil, cells $/ \mu \mathrm{L}$ & $7.9(5.8-10.2)$ & $7.1(4.8-10.8)$ & 0.625 \\
\hline Lymphocyte, cells/ $\mu \mathrm{L}$ & $0.9(0.5-1.4)$ & $0.7(0.4-1.1)$ & 0.058 \\
\hline $\mathrm{MPV}, \mathrm{fL}$ & $10.0(9.4-10.8)$ & $10.0(9.4-10.9)$ & 0.828 \\
\hline Creatinine, $\mathrm{mg} / \mathrm{dL}$ & $1.2(0.9-1.6)$ & $1.3(1.0-1.9)$ & 0.193 \\
\hline Urea, mg/dL & $52(28-84)$ & $61(41-104)$ & $0.048^{*}$ \\
\hline AST, U/L & $41(21-60)$ & $32(22-49)$ & 0.299 \\
\hline ALT, U/L & $34(19-62)$ & $22(15-42)$ & 0.064 \\
\hline C-reactive protein, $\mathrm{mg} / \mathrm{dL}$ & $85.4(49.7-129.0)$ & $132.5(67.0-185.0)$ & $0.003^{*}$ \\
\hline D-dimer, $\mathrm{ng} / \mathrm{mL}$ & $669(335-1490)$ & $1430(790-3550)$ & $0.002^{*}$ \\
\hline Procalcitonin, ng/mL & $0.24(0.08-1.28)$ & $0.57(0.17-3.20)$ & $0.048^{*}$ \\
\hline Lactate dehydrogenase, U/L & $636(453-792)$ & 659 (465-969) & 0.295 \\
\hline Ferritin, $\mathrm{ng} / \mathrm{mL}$ & $476(170-1192)$ & $619(340-1681)$ & 0.295 \\
\hline Troponin, ng/mL & $24.6(5.8-200.0)$ & $45.6(14.3-236.0)$ & 0.180 \\
\hline N/LP ratio & $2.86(1.73-7.05)$ & $5.06(2.98-8.64)$ & $0.017^{*}$ \\
\hline
\end{tabular}

Continuous variables are presented as median values and interquartile ranges (IQRs), and nominal variables as frequencies. ${ }^{*} p<0.05$

Abbreviations: MPV: mean platelet volume; AST: aspartate aminotransferase, ALT: alanine aminotransferase; N/LP: neutrophil to lymphocyte platelet ratio 
were analyzed in this investigation. Each member of the research cohort was categorized into one of two groups based on their survival status (survivor and non-survivor groups) (Table 1). There were 52 (38\%) patients in the survivor group and 82 $(62 \%)$ patients in the non-survivor group. A total of $29(55.8 \%)$ participants in the survivor group and $52(63.4 \%)$ participants in the non-survivor group were male. The groups were similar in terms of the following risk factors: diabetes mellitus, hypertension, chronic obstructive pulmonary disease, asthma, chronic renal failure,

Table 3. Laboratory variables of all cases on the day of intubation.

\begin{tabular}{|c|c|c|c|}
\hline & $\begin{array}{l}\text { Survivors } \\
(\mathrm{n}=52)\end{array}$ & $\begin{array}{l}\text { Non-survivors } \\
(\mathrm{n}=\mathbf{8 2})\end{array}$ & p value \\
\hline Hemoglobin, g/dL & $11.3(9.7-13.5)$ & $10.5(9.3-12.6)$ & 0.085 \\
\hline White blood cell count, cells $/ \mu \mathrm{L}$ & $9.0(6.4-11.8)$ & $13.3(9.7-17.0)$ & $<0.001$ ** \\
\hline Platelet count, cells $/ \mu \mathrm{L}$ & $265(204-395)$ & $219(129-290)$ & $0.001^{*}$ \\
\hline Neutrophil, cells $/ \mu \mathrm{L}$ & $7.3(4.9-9.7)$ & $12.1(8.0-15.6)$ & $<0.001^{* *}$ \\
\hline Lymphocyte, cells $/ \mu \mathrm{L}$ & $0.9(0.7-1.3)$ & $0.5(0.3-1.0)$ & $<0.001^{* *}$ \\
\hline MPV, fL & $10.0(9.3-10.6)$ & $10.3(9.6-11.4)$ & 0.064 \\
\hline Creatinine, $\mathrm{mg} / \mathrm{dL}$ & $1.0(0.8-1.4)$ & $1.3(0.9-2.1)$ & $0.032 *$ \\
\hline Urea, mg/dL & $44(31-80)$ & $77(43-123)$ & $<0.001^{* *}$ \\
\hline AST, U/L & $26(17-53)$ & $39(25-61)$ & $0.021 *$ \\
\hline ALT, U/L & $34(17-81)$ & $29(19-67)$ & 0.735 \\
\hline C-reactive protein, $\mathrm{mg} / \mathrm{dL}$ & $38.0(9.6-77.1)$ & $123.5(72.0-177.0)$ & $<0.001^{* *}$ \\
\hline D-dimer, ng/mL & $1090(616-2340)$ & $1920(1230-4830)$ & $<0.001$ ** \\
\hline Procalcitonin, ng/mL & $0.12(0.05-0.95)$ & $0.89(0.29-3.10)$ & $<0.001^{* *}$ \\
\hline Lactate dehydrogenase, U/L & 543 (409-776) & $864(548-1270)$ & $<0.001^{* *}$ \\
\hline Ferritin, ng/mL & $350(161-720)$ & $759(458-2000)$ & $<0.001^{* *}$ \\
\hline Troponin, ng/mL & $12.0(4.1-114.0)$ & $81.5(25.9-640.0)$ & $<0.001^{* *}$ \\
\hline N/LP ratio & $2.51(1.67-5.49)$ & $10.0(4.94-19.38)$ & $<0.001^{* *}$ \\
\hline
\end{tabular}

Continuous variables are presented as median values and interquartile ranges (IQRs), and nominal variables as frequencies. ${ }^{*} p<0.05,{ }^{* *} p<0.001$

Abbreviations: MPV: mean platelet volume; AST: aspartate aminotransferase, ALT: alanine aminotransferase; N/LP: neutrophil to lymphocyte platelet ratio

Table 4. Laboratory variables on the day of mortality.

\begin{tabular}{|c|c|c|c|}
\hline & $\begin{array}{l}\text { Survivors } \\
(\mathbf{n}=52)\end{array}$ & $\begin{array}{l}\text { Non-survivors } \\
(\mathbf{n}=\mathbf{8 2})\end{array}$ & p value \\
\hline Hemoglobin, g/dL & $10.9(9.9-13.1)$ & $9.6(8.4-11.4)$ & $<0.001^{* *}$ \\
\hline White blood cell count, cells $/ \mu \mathrm{L}$ & $8.4(6.6-11.1)$ & $15.0(9.9-21.2)$ & $<0.001^{* *}$ \\
\hline Platelet count, cells $/ \mu \mathrm{L}$ & $267(205-344)$ & $140(67-271)$ & $<0.001^{* *}$ \\
\hline Neutrophil, cells $/ \mu \mathrm{L}$ & $5.6(4.4-8.1)$ & $12.8(7.7-19.2)$ & $<0.001^{* *}$ \\
\hline Lymphocyte, cells $/ \mu \mathrm{L}$ & $1.3(0.9-1.8)$ & $0.8(0.3-1.4)$ & $<0.001^{* *}$ \\
\hline MPV, fL & $9.8(9.3-10.5)$ & $11.0(9.8-12.1)$ & $<0.001^{* *}$ \\
\hline Creatinine, $\mathrm{mg} / \mathrm{dL}$ & $1.0(0.8-1.2)$ & $1.9(1.2-3.7)$ & $<0.001^{* *}$ \\
\hline Urea, mg/dL & $36(27-67)$ & $117(73-171)$ & $<0.001^{* *}$ \\
\hline AST, U/L & $25(16-41)$ & $47(27-103)$ & $<0.001^{* *}$ \\
\hline ALT, U/L & $38(17-91)$ & $39(18-96)$ & 0.953 \\
\hline C-reactive protein, $\mathrm{mg} / \mathrm{dL}$ & $14.8(2.0-36.5)$ & $123.0(59.0-179.0)$ & $<0.001^{* *}$ \\
\hline D-dimer, $\mathrm{ng} / \mathrm{mL}$ & $581(335-1280)$ & $2460(1320-5470)$ & $<0.001^{* *}$ \\
\hline Procalcitonin, ng/mL & $0.09(0.04-0.30)$ & $2.10(0.76-7.00)$ & $<0.001^{* *}$ \\
\hline Lactate dehydrogenase, U/L & $463(391-546)$ & 948 (548-1459) & $<0.001^{* *}$ \\
\hline Ferritin, $\mathrm{ng} / \mathrm{mL}$ & $358(209-664)$ & $1282(536-2000)$ & $<0.001^{* *}$ \\
\hline Troponin, ng/mL & $7.5(3.7-59.0)$ & $123.0(30.1-762.0)$ & $<0.001^{* *}$ \\
\hline N/LP ratio & $1.65(1.00-3.24)$ & $11.27(4.53-30.02)$ & $<0.001^{* *}$ \\
\hline
\end{tabular}

Continuous variables are presented as median values and interquartile ranges (IQRs); nominal variables as frequencies. ${ }^{*} p<0.05,{ }^{* *} p<0.001$

Abbreviations: MPV: mean platelet volume; AST: aspartate aminotransferase, ALT: alanine aminotransferase; N/LP: neutrophil to lymphocyte platelet ratio 
B. Cakir Guney et al. Evaluation of N/LP Ratio as a Predictor of Disease Progression and Mortality in COVID-19 Patients Admitted to the Intensive Care Unit

cerebrovascular accident, and congestive heart failure.

Table 2 presents the laboratory results of all patients upon admission to the ICU. Non-survivor patients had lower platelet counts but higher urea, CRP, D-dimer, and procalcitonin levels than those who survived. Remarkably, the N/LP ratios were significantly higher in the patients who did not survive than in those who survived (5.06 [IQR=2.98-8.64] vs 2.86 [IQR=1.73-7.05] respectively, $p=0.017$ ). There was no other statistically significant difference between the survivors and non-survivors in terms of laboratory findings.
Table 3 displays the laboratory data of all cases on the day of intubation. WBC and neutrophil counts and levels of troponin, D-dimer, procalcitonin, lactate dehydrogenase, ferritin, and CRP were significantly higher in the patients who required mechanical ventilation. Additionally, on their day of intubation, non-surviving patients exhibited significantly higher N/LP ratios than those who survived $(10[I Q R=4.94-19.38]$ vs $2.51[I Q R=1.67$ 5.49], respectively, $p<0.001$ ). On the other hand, these patients had significantly lower platelet and lymphocyte counts.

As shown in Table 4, we also compared the laboratory findings of the surviving and nonsurviving patients on the day of mortality. On the

Table 5. Univariable and multivariable analyses for admission to the ICU, on the day of intubation and in-hospital mortality.

\begin{tabular}{lllll} 
& Univariable analysis & & Multivariable analysis \\
\cline { 5 - 6 } P value & $\begin{array}{l}\text { OR } \\
(95 \% \mathrm{CI})\end{array}$ & & P value & $\begin{array}{l}\text { OR } \\
(95 \% \mathrm{CI})\end{array}$
\end{tabular}

\begin{tabular}{lcc}
\hline On admission to the ICU & & \\
Age & $0.007^{*}$ & $1.036(1.010-1.063)$ \\
Platelet & $0.004^{*}$ & $0.995(0.991-0.998)$ \\
C-reactive protein & $0.003^{*}$ & $1.008(1.003-1.014)$ \\
N/LP ratio & 0.678 & $1.000(0.999-1.002)$ \\
On the day of intubation & & \\
Platelet & $<0.001^{* *}$ & $0.994(0.991-0.998)$ \\
Neutrophil & $<0.001^{* *}$ & $1.002(1.001-1.004)$ \\
MPV & $0.019^{*}$ & $1.435(1.062-1.938)$ \\
Urea & $<0.001^{* *}$ & $1.020(1.010-1.031)$ \\
C-reactive protein & $<0.001^{* *}$ & $1.019(1.011-1.027)$ \\
D-dimer & $0.002^{*}$ & $1.001(1.000-1.002)$ \\
LDH & $<0.001^{* *}$ & $1.002(1.001-1.003)$ \\
N/LP ratio & $<0.001^{* *}$ & $1.225(1.110-1.351)$ \\
On the day of mortality & & \\
White blood cells count & $0.001^{*}$ & $1.096(1.038-1.156)$ \\
Hemoglobin & $<0.001^{* *}$ & $0.715(0.599-0.855)$ \\
Platelets & $<0.001^{* *}$ & $0.992(0.989-0.996)$ \\
Neutrophil & $<0.001^{* *}$ & $1.002(1.001-1.004)$ \\
MPV & $<0.001^{* *}$ & $1.848(1.357-2.518)$ \\
Urea & $<0.001^{* *}$ & $1.030(1.019-1.042)$ \\
Creatinine & $0.004^{*}$ & $1.458(1.124-1.890)$ \\
AST & $0.013^{*}$ & $1.015(1.003-1.027)$ \\
C-reactive protein & $<0.001^{* *}$ & $1.031(1.020-1.043)$ \\
D-dimer & $<0.001^{* *}$ & $1.001(1.000-1.001)$ \\
Procalcitonin & $<0.001^{* *}$ & $6.294(2.597-15.255)$ \\
LDH & $<0.001^{* *}$ & $1.004(1.003-1.006)$ \\
N/LP ratio & $<0.001^{* *}$ & $1.375(1.182-1.600)$ \\
& & \\
\hline
\end{tabular}

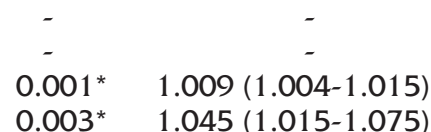

$0.003^{*} \quad 1.045(1.015-1.075)$
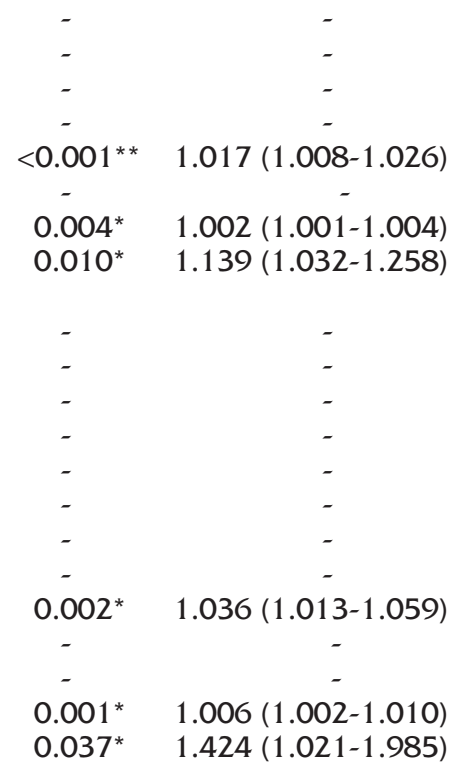

All clinically relevant parameters were included in the model. ${ }^{*} p<0.05,{ }^{* *} p<0.001$

Abbreviations: OR: odds ratio; $\mathrm{CI}$ :confidence interval; ICU: intensive care unit; MPV: mean platelet volume; AST: aspartate aminotransferase; LDH: lactate dehydrogenase; N/LP: neutrophil to lymphocyte platelet ratio 
day of mortality, we observed that non-surviving patients had lower hemoglobin, platelets, and lymphocyte count but higher WBC as well as higher neutrophil, CRP, D-dimer, procalcitonin, urea, creatinine, lactate dehydrogenase, ferritin, and troponin levels. In addition, non-surviving patients on the day of mortality had significantly higher N/LP ratios than those who survived (11.27 [IQR=4.53-30.02] vs 1.65 [IQR=1-3.24] respectively, $\mathrm{p}<0.001$ ).

To determine the independent predictors for admission to the ICU, mechanical ventilation, and in-hospital mortality, both univariable and multivariable analyses were performed (Table 5). Based on the multivariable analysis, only CRP and the N/LP ratio (Odds ratio [OR]: 1.045, 95\% confidence interval [CI]:1.015-1.075, $\mathrm{p}=0.003$ ) were independent predictors for admission to the ICU. Furthermore, CRP and lactate dehydrogenase levels and the N/LP ratio (OR: $1.139,95 \% \mathrm{CI}$ : 1.032-1.258, $p=0.010$ ) were independently linked with the need for mechanical ventilation. In addition, these parameters, including the N/LP ratio (OR: $1.424,95 \% \mathrm{Cl}$ : 1.021-1.985, $\mathrm{p}=0.037$ ), were independently linked to in-hospital death.

In the ROC analysis, we found that the N/LP ratio predicted admission to the ICU with an ideal cut-off value of $>4.18,61 \%$ sensitivity and $62 \%$ specificity; the need for mechanical ventilation

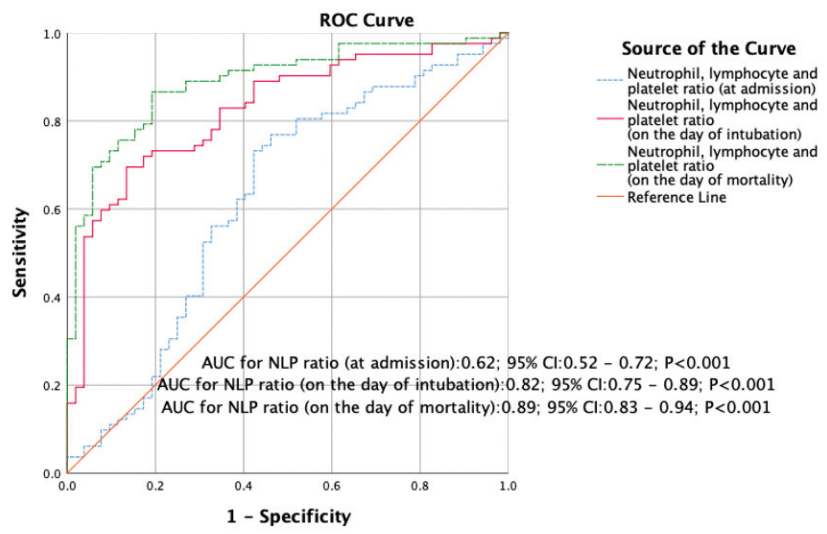

Figure 1. A receiver operating characteristics curve illustrating the associations between neutrophil to lymphocyte and platelet (N/LP) ratios and ICU admission, mechanical ventilation and in-hospital mortality. with an ideal cut-off value of $>5.07,74 \%$ sensitivity and $73 \%$ specificity; and in-hospital death with an ideal cut-off value of $>3.69,81 \%$ sensitivity and $81 \%$ specificity (Figure 1 ).

\section{DISCUSSION}

The present investigation found that the N/LP ratio could be used to predict in-hospital death and ICU admission in COVID-19 patients. COVID19 infection can progress rapidly, especially in patients with significant risk factors. In a recent meta-analysis examining the subjects admitted to the ICU due to COVID-19 infection in Italy, advanced age and male gender were linked with elevated mortality rates in COVID-19 patients ${ }^{10}$. In another meta-analysis that included 20,133 patients, the average age of non-surviving COVID19 patients was 70 years, and male gender was an independent risk factor for COVID-19-related death ${ }^{11}$. In a prior study conducted in Italy, Petretto et al. ${ }^{12}$ examined the cases of 3,200 patients who died during the index hospitalization, and they found that the most frequently observed comorbidities were hypertension, diabetes, and ischemic heart disease. In another multi-center study of the ICU patients in Spain, it was found that the average age of the subjects who died during in-hospital stays was higher than that of patients who were discharged ${ }^{13}$. In our study, 134 subjects who were followed up in the ICU were compared. The average age of the patients who died was 72 years, and this was higher than the average age of the surviving patient group. However, our results show that age was not an independent predictor for admission to the ICU, the need for mechanical ventilation or in-hospital death in subjects with COVID-19 disease.

In a previous study examining 3,988 ICU patients in Lombardy, Italy, hypertension was the most common chronic disease, followed by diabetes, chronic pulmonary disease, and ischemic cardiac disease ${ }^{14}$. There was no statistically significant gender difference between the patients who died 
in the ICU and those who survived. In our study, we found no statistically significant difference between the survivors and non-survivors in terms of gender.

In a recent investigation that included 343 patients in China, D-dimer levels were significantly higher in COVID-19 patients who died than in the survivors ${ }^{15}$. Moreover, Selcuk et al. ${ }^{16}$ showed that the D-dimer levels of COVID-19 patients were significantly higher than those of the surviving patients. In addition, Liu et al. ${ }^{17}$ found that high levels of inflammatory markers played an important role in the assessment of the severity of COVID19 disease, and they reported that these markers were significantly elevated in patients with COVID19. We found similar results in our study: High CRP and D-dimer values were correlated with the severity of COVID-19 disease. However, only CRP level was an independent biochemical marker for in-hospital death in the COVID-19 cases that we examined. In addition, in the non-surviving cases we examined, CRP levels were significantly higher on the day of admission to the ICU and before intubation than in the surviving patients.

In a recent investigation, Seyit et al. ${ }^{18}$ examined the neutrophil/lymphocyte ratio (NLR) and the platelet/lymphocyte ratio (PLR) to evaluate the effects of hematological variables on in-hospital death in the patients with COVID-19 disease. The results clearly showed that NLR and PLR ratios were significantly elevated in exited COVID-19 patients ${ }^{18}$. A recent meta-analysis of the data from 3,508 COVID-19 patients was conducted to determine the prognostic role of NLR and PLR in the assessment of the progression of COVID-19 disease. NLR and PLR were found to be significantly correlated with the severity of COVID-19 disease ${ }^{19,20}$.

The N/LP ratio, which was also investigated in our study, was previously found to predict acute renal failure and mortality in patients with sepsis as well as following abdominal surgery and cardiovascular surgery $^{7-9}$. As a result of these studies, the NL/P ratio was linked with a higher incidence of acute renal injury and mortality ${ }^{7-9}$. Gameiro et al. ${ }^{7}$ identified a correlation between the N/LP ratio and death in the patients with septic renal failure. The ideal cut-off value was $>14$, with a positive predictive value of 1.63 and a negative predictive value of 0.84 , meaning that almost $80 \%$ of the subjects with an N/LP ratio lower than 14 could survive. It was concluded that the $\mathrm{N} / \mathrm{LP}$ ratio could be utilized to facilitate patient stratification and to assess the risk of disease progression. In our study, the ideal cut-off value was $>3.69$, with $81 \%$ sensitivity and $81 \%$ specificity in predicting in-hospital death in COVID-19 subjects. We identified a statistically significant difference between our patient groups in terms of mechanical ventilation, ICU admission, in-hospital death, and this difference was correlated with the $\mathrm{N} /$ LP ratios. Thus, the N/LP ratio appears to be an effective inflammatory marker for the risk of ICU admission, mechanical ventilation, and in-hospital death in patients with COVID-19 disease.

Our results are valuable for daily clinical practice. Due to the excess number of patients in the current pandemic, patients with ARDS are admitted to the ICU. The in-hospital death rate is approximately $60 \%$ in these patients ${ }^{4}$. Thus, based on the study findings, we have concluded that the N/LP ratio, an easily obtained inflammatory parameter, can be used to predict the risk of mechanical ventilation, ICU admission, and in-hospital death in hospitalized COVID-19 patients.

\section{Study limitations}

The retrospective nature of this study is among the most important limiting factors. Although the power analysis showed the presence of an adequate sample size, the study also included a limited number of cases. In addition, although a multivariate analysis was conducted to identify independent predictors, some unmeasured confounders might be present and affected the results of the study. Finally, spot laboratory data 
were used to evaluate the relationships between the N/LP ratios and the ICU admissions, in-hospital mortality, the need for mechanical ventilation. More prospective studies with larger sample sizes are needed to confirm the relationship between in-hospital death and the N/LP ratio in COVID-19 patients.

\section{CONCLUSION}

The current investigation shows that the N/LP ratio can be used to predict the risk of mechanical ventilation, ICU admission, and in-hospital death in the subjects with COVID-19 disease.

\section{REFERENCES}

1. WHO Coronavirus (COVID-19) Dashboard. Available from: https://covid19.who.int/

2. Revel MP, Parkar AP, Prosch H, et al. COVID-19 patients and the radiology department - advice from the European Society of Radiology (ESR) and the European Society of Thoracic Imaging (ESTI). Eur Radiol. 2020;30:4903-9. [CrossRef]

3. Selçuk M, Keskin M, Çınar T, et al. Prognostic significance of N-Terminal Pro-BNP in patients with COVID-19 pneumonia without previous history of heart failure. J Cardiovasc Thorac Res. 2021;13:141-5. [CrossRef]

4. Li X, Ma X. Acute respiratory failure in COVID-19: is it "typical" ARDS?. Crit Care. 2020;24:198. [CrossRef]

5. Tjendra Y, Al Mana AF, Espejo AP, et al. Predicting disease severity and outcome in COVID-19 patients: a review of multiple biomarkers. Arch Pathol Lab Med. 2020;144:1465-74. [CrossRef]

6. Güney BÇ, Taştan YÖ, Doğantekin B, et al. Predictive value of CAR for in-hospital mortality in patients with COVID19 pneumonia: a retrospective cohort study. Arch Med Res. 2021;52:554-60. [CrossRef]

7. Gameiro J, Fonseca JA, Jorge S, Gouveia J, Lopes JA. Neutrophil, lymphocyte and platelet ratio as a predictor of mortality in septic-acute kidney injury patients. Nefrologia (Engl Ed). 2020;40:461-8. [CrossRef]

8. Gameiro J, Fonseca JA, Dias JM, et al. Neutrophil, lymphocyte and platelet ratio as a predictor of postoperative acute kidney injury in major abdominal surgery. BMC Nephrol. 2018;19:320. [CrossRef]

9. Koo CH, Eun Jung D, Park YS, et al. Neutrophil, lymphocyte, and platelet counts and acute kidney injury after cardiovascular surgery. J Cardiothorac Vasc Anesth. 2018;32:212-22. [CrossRef]

10. Pijls BG, Jolani S, Atherley A, et al. Demographic risk factors for COVID-19 infection, severity, ICU admission and death: a meta-analysis of 59 studies. BMJ Open. 2021;11:e044640. [CrossRef]

11. Docherty AB, Harrison EM, Green CA, et al. Features of 20 133 UK patients in hospital with covid-19 using the ISARIC WHO Clinical Characterization Protocol: prospective observational cohort study. BMJ. 2020;369:m1985. [CrossRef]

12. Petretto DR, Pili R. Ageing and COVID-19: what is the role for elderly people? Geriatrics (Basel). 2020;5:25. [CrossRef]

13. Ferrando C, Mellado-Artigas R, Gea A, et al. Patient characteristics, clinical course and factors associated to ICU mortality in critically ill patients infected with SARSCoV-2 in Spain: A prospective, cohort, multicentre study. Rev Esp Anestesiol Reanim (Engl Ed). 2020;67:425-37. [CrossRef]

14. Grasselli G, Greco M, Zanella A, et al. Risk factors associated with mortality among patients with COVID-19 in intensive care units in Lombardy, Italy. JAMA Intern Med. 2020;180:1345-55. [CrossRef]

15. Zhang L, Yan X, Fan Q, et al. D-dimer levels on admission to predict in-hospital mortality in patients with Covid-19. J Thromb Haemost. 2020;181324-9. [CrossRef]

16. Selcuk M, Cinar T, Gunay N, et al. Comparison of D-dimer level measured on the third day of hospitalization with admission D-dimer level in predicting in-hospital mortality in COVID-19 patients. Medeni Med J. 2021;36:1-6. [CrossRef]

17. Liu F, Li L, Xu M, et al. Prognostic value of interleukin-6, C-reactive protein, and procalcitonin in patients with COVID-19. J Clin Virol. 2020;127:104370. [CrossRef]

18. Seyit M, Avci E, Nar R, et al. Neutrophil to lymphocyte ratio, lymphocyte to monocyte ratio and platelet to lymphocyte ratio to predict the severity of COVID-19. Am J Emerg Med. 2021;40:110-14. [CrossRef]

19. Chan AS, Rout A. Use of neutrophil-to-lymphocyte and platelet-to-lymphocyte ratios in COVID-19. J Clin Med Res. 2020;12:448-53. [CrossRef]

20. Zheng Y, Zhang Y, Chi H, et al. The hemocyte counts as a potential biomarker for predicting disease progression in COVID-19: a retrospective study. Clin Chem Lab Med. 2020;58:1106-15. [CrossRef] 